Staropolska grzeczność. O pobycie króla Władysława IV w gościnie u Stanisława Radziejowskiego w 1632 roku w świetle okolicznościowego pisma Hospes grati animi

Maria Wichowa 


\title{
Staropolska grzeczność. O pobycie króla Władysława IV w gościnie u Stanisława Radziejowskiego w 1632 roku w świetle okolicznościowego pisma Hospes grati animi...
}

\begin{abstract}
$\mathrm{A}$ nalizowane dzieło, wydane bezimiemnic (jak się wydaje, w rokı 1633, być może w drukarni Jana Rossowskiego)', ma charakter okolicznościowy. Jest poświęcone opisowi uroczystości, które mialy miejsce w dniach 22-25 listopada 1632 roku z okazji wizyty świeżo powołanego na tron króla Wladysława IVw Radzicjowicach ${ }^{2}$. Monarcha przybył tam, aby podać do chrztu synka Stanisława Radziejowskiego; i ta ceremonia jest również relacjonowana w Hospes...

Przyjazd króla do rezydencji wojewody lęczyckiego stanowil wielki splendor dla anbitnego gospodarza. Rodzina Radzicjowskich długi czas sytuowała się wśród średniozannożnej szlachty, więc wojewoda lęczycki był homo nor'ıs wśród magnatów Rzeczypospolitej. On pier-
\end{abstract}

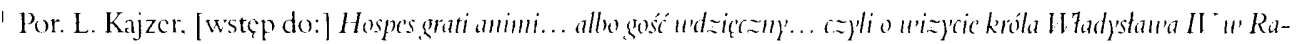
d:icjouricad u' rokn 1632, th. J. Danka, wst. i koment. L. Kajzer. Lódź 20(12, s. III.

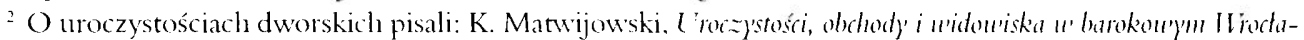

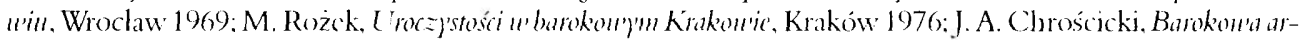

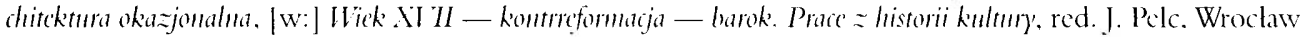

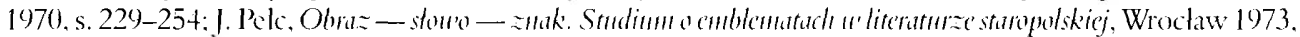

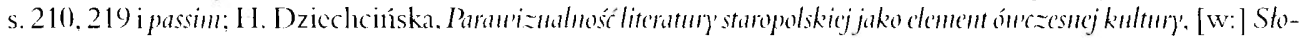

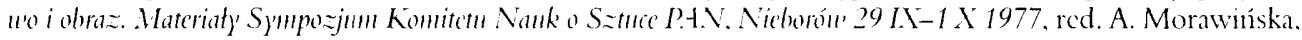
Warszawa 1982, s. 97-112; cadem. Ogladanie i stuchanie " kulturze dun'nej Polski. Warszawa 1987, s. 8.3-154. rozdz. 2: II izmalmośc literatmy' stamopolskicj: T. Chrzanowski, Samatyzm - mity darne i uspótezesnc. [w:] idem,

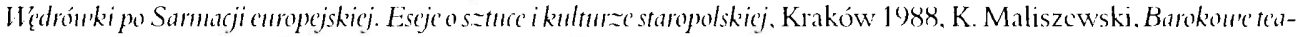

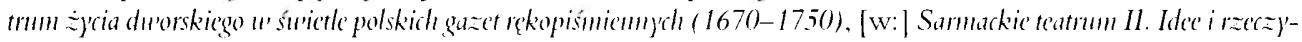

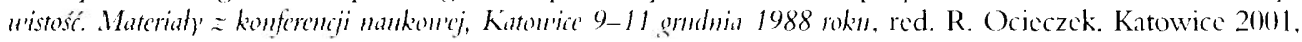
s. $190-20(0$. 
wszy w swym rodzie osiągnąl senatorską godność. Umiejçtnie piąl się w górę, zjednując sobie łaskę królewską i przemyślnie zawierając związki malżeńskie. Po raz pierwszy ożenił się z Katarzyną Sobieską, córką Marka, wojewody lubelskiego, po raz drugi z Krystyną Sapieżanką, córką Jana Piotra, starosty uświackiego. Spowinowacił się z pierwszymi domami kraju, wziąl kolejno dwie posażne panny i z szlachcica przeobraził się w pana ${ }^{3}$. Względy monarchy zyskał

...sprytem, dobrym humorem, wierną wysługą dworską, a nade wszystko gościnnościąt.

Z dworem królewskim Radziejowscy byli związani od dawna. Dziad Stanisława - Mikotaj - służy na dworze Katarzyny Jagiellonki, następnie piastował godność marszalka dworu Anny. Sprawował urzędy kasztelana gostyńskiego, potem wojewody plockiego; powiększał majątek, pożyczał władcy pieniądze pod zastaw królewszczyzn, obejmował intratne starostwa, z sochaczewskim na czele. W następnym pokoleniu Radziejowscy podupadli. Do grona magnatów dołączył dopiero Stanisław, wkraczając w krąg elity swoich czasów. Odbył podobno jakieś studia zagraniczne. pisal też jakoby wiersze lacińskie, ale dziś nie wiadomo, co to były za teksty".

W jego majątku rodowym, Radziejowicach, położonych w odległości $45 \mathrm{~km}$ na zachód od Warszawy, około 1606 roku zbudowano murowany pałac". Znajdowały się tam też:

...karczma na dwieście koni, budynki dworskie na tysiąc gości, kilkanaście dzialek wiwatowych, niewyczerpana piwnica i znakomita kuchnia?

Tam wojewoda lęczycki podejmowat podążających do stolicy dostojnych gości: poselstwa zagraniczne, polskich poslów i senatorów, a nawet monarchów - Zygmunta III, a potem Władysława IV. Radziejowski słynął z gościmności. Lıdwik Kubala trochę złośliwie komentowal ten fakt stowani:

W calej Polsce nie bawiono się tak wesoło, dostatnio i swobodnie, jak w Radziejowicach. Zdaje się, że to byly najważniejsze zasługi, jakie stary wojewoda oddat krajowi ${ }^{8}$.

Ambitny magnat staramnie pięlęgnowal związki z dworem królewskim. Starał się wszelkimi sposobami zdobyć przychylność, a wręcz życzliwość króla i jego najbliższych. Miał bardzo dobre relacje z Zygmuntem III (podobno był on dziesięć razy w Radziejowicach, także jego żona Konstancja lubiła tam przebywać) i jego synem Władysławem, który bywał częstym go-

${ }^{3}$ Por. L. Kubalu, Proces Radzicjou'skiego. [w: | idem. Szkice historyezle, seria 2, Lwów 1880, s. $t$.

+ L. Kubala. op. cit.. s. 4.

"Por. A. Kersten, Hicromim Ratzicjowski. Studimm whalzy' i opozyeji, Warszawa 1988. s. 20.

"Por. A. Kersten, op. cit., s. 27; L. Kajzer, op. cit., s. XIII.

${ }^{7}$ Cyt. za: L. Kubala, op. cit., s. 4.

'Ibide'm, s. 4. 
ściem u Radziejowskiego i wzajemnic zapraszal wojewodę na dwór lub na polowanie do ulubionego Merecza na Litwie".

Przyjazd do Radziejowic Whadysława IV, obranego królem 14 listopada 1632 roku, stanowil wielki zaszczyt dla gospodarza, który przyjmowal władcę okazale, wystawnie, manifestıjąc w ten sposób wielkość swojego domu. Druczek okolicznościowy Hospes grati animi... doskonale tę atmosferę oddaje.

Autor panegiryku podkreślał, że wyjątkowy splendor spotkał wojewodę lęczyckiego, skoro król Whadysław IV tuż po zakończeninu ceremonii elekcji gościl u Radziejowskiego w jego gnieździe rodzinnym, co jest wyrazem szczególnej laski monarchy, przywilejen wyjątkowym. W swej królewskiej dobroci uzual go godnym, aby odwiedzić go jako pierwszego i uświetnić uroczystości w rodzinie gospodarza, przed wszystkimi innymi domami, które rade by byly władcę podejmować w swojej siedzibie. Zamieścił caly passus poświęcony przedstawieniu licznych cnót najjániejszego pana, a przede wszystkim jego ludzkości. Przymiotnik „najjaśniejszy” jest, jak wiadomo, często stosowanym określeniem władcy, ale ma on wartość nic tylko zwrotu grzecznościowego. Odzywa się w tym także powszechne przekonanie o wyjątkowej randze osoby króla. Przypomnijmy fragment kazania Idea regis Daniela Kałaja (z 12 czerwca 1673 roku), który sens tego wyjaśnia następująco:

To król na ziemi, co słońce na niebie.

Ów sentencjonalny zwrot doczekal się szerszego komentarza autora:

Wielkość słońca w królach jest znaczna. Wielkimi są nie tylko w ludzkich, co słuszna, ale i w Boskich oczach. Wysokość miejsca z stońcem in należy. Bo Najwyższego są namiestnikami, którego stolicą niebo, a ziemia podnóżkiem. Bieg ich fortıny i spraw chwalebnych na wschód i na zachód przysięga, i zastanowiony być tą ręką może, która go prowadzi i serca ich trzyma. Rząd i władza królów wielka ze wszech miar, która im z nieba dana. Jako słońce, na nicbie będąc, rządzi dniem i czasami, tak król, siedząc na stolicy swojej, rozgania wszystko zle oczyma swymi".

Tak więc w świetle Hospes. . najjaśniejszy Wladysław, obdarzony wszystkimi królewskimi cnotami i stałym charakterem, dojrzałością i powagą w radzie, znakomitą wrodzoną zdolnością przyswajania wszystkiego, co dobre, talentani oratorskimi, odznacza się takze ludzkością, przyjacielskością, niesłychaną dobrocią we wszystkich myślach, a zatem godzien jest najwyższego podziwu. W panegiryku tym autor, inspirowany przez Radzicjowskiego, na każdym kroku podkreśla wielki szacunek, cześć okazywania królowi. Raz po raz z największym respektem mówi o godności i majestacie przebywającego w gościnie władcy:

"Por. W. Kloczowski. Radzicjouski Stamistan" [w":] Polski stommik biognafiz-n]' t. 30, Wroclaw 1987. s. 79-81.

"'Cyt. za: E. Kotarski, Muza gdanska Jamoni III Solveskicmm 1673-1696. Wroclaw 1985, s. 18. 
Oddałeś się zatem, Królu Najjaśniejszy, męstwu twojemu i twojej dobroci. Dobrocią i majestatem twoim królewskim w domu senatora twego zajaśniałeś (s. 6).

Czołobitność panegirysty, oddająca także postawę gospodarza, jest tu przejawem dobrych obyczajów staropolskiej grzeczności, tej wyrafinowanej, szlacheckiej, której arkana Radziejowski opanowal do perfekcji. Zasłużył na to, głosi autor, zeby być nazwanym „królem stołu królewskiego". Ze względu na sławę władcy i państwa przyjmował posłów polskich i posłów obcych królów i książąt, okazując im wiclką uprzejmość, ofiarowując gościnę. Drzwi jego domı stały dla wszystkich otworem, a każdy wychodzil stamtąd zadowolony. Whadysław zaszczycił swego wiernego przyjaciela i poddanego, uwzględniając jego zgoła wyjątkowe zasługi dla dworu:

Kiedy to Król Najjaśniejszy nasz Whadysław i królewicze najiaśniejsi spostrzegli, bardzo się o to starali, aby w tobie tak dla siebie oddanego i spraw swoich najwierniejszego powiernika pozyskać, pokładając [w tobie] swoją dobroć i przychylność laski.

A zatem nie chcieli, aby pierwsza wyprawa najjaśniejszych, po szczęśliwej w Królestwie Polskim elekcji najjaśniejszego ich brata Władysława, byla inna jak do twojego domu, aby tobie z miłej duszy i przychylności w twoich progach pamiątkę zostawić. $Z$ tego powodu i syna twojego w domu swoim wlasnym ochrzcić postanawiają i na wieczną pamiątkę imieniem Wladysława nazwać, i licznymi darami, i wielkimi dowodami miłości [obdarzyć] dom twój, w którym swobodnie i wesoło, tak jak u siebie, kilka dni spędzić i rozjaśnić, po okazaniu najliczniejszych życzliwości i wdzięczności (...), po wysłuchaniu próśb, przeprosin i uznań twoich na rzecz innych zasług twoich, dla ciebie i twojego potomstwa najsprawiedliwszymi wynagrodzeniami, najpobożniej nadto przyobiecanymi (s. 22).

Jak widać, staropolska nauka o grzeczności naktadała poważne i liczne obowiązki na gospodarza. Przyslowie „gość w dom, Bóg w dom” jest odzwierciedleniem tego zjawiska. W Radziejowicach zadbano, aby dostojnych gości przyjąć z największymi honorami i z najokazalszym przepychem, z zachowaniem tradycji i obyczajów.

Dziełko Hospes grati animi... podaje szczegółową relację z tych wydarzeń. Wedle omawianego pisma król Whadysław pojawil się ze swym dworem w okolicy Radziejowic w poniedziatek 22 listopada 1632 roku. Towarzyszyli mu bracia: Jan Kazimierz, Jan Wojciech, Karol Ferdynand i Aleksander Karol. Gospodarz od jakiegoś czasu oczekiwał znakomitych gości i wraz z synami wyjechat im na spotkanie, bo tego wymagala grzeczność. Jej nakazy zobowiązywały także przybywających, aby pojawili siç nieco wczéśniej, by dlugim oczekiwaniem nie trudzić witających. Również zgodnie ze staropolskim obyczajem Radziejowski wygłosił mowę powitalną, a następnie wprowadzil gości do „własnego domu”, w którym przyjmowała przybyłych jego żona, ,.matka rodziny, otoczona dość licznym i wybranym wieńcem kobiet”. .. Najjaśniej- 
si" przyjęli pozdrowienie, zezwolili na ucałowanie ręki. Byl to ważny element etykiety. Obowiązywala zasada, że niżsi w hierarchii społecznej całowali rękę usytuowanych wyżej. Powszechnie całowano ręce kobietom i doroślejszym pannom, z kolei młode niewiasty całowały ręce matkom. W Radziejowicach miała miejsce ceremonia całowania ręki królewskiej. Był to dowód laski monarchy.

...król najjaśniejszy i najjaśniejsi bracia postanowili pozdrowienie przyjać, na pocałmek ręki dozwolić i wszystkim innym wtedy obecnym także, które [to kobiety] dookola i naprzeciwko siebie w pozdrowieniu obeszli (s. 31).

Jak widać, damy stały w okręgu i do każdej z nich podchodził król, pozdrawiając je i dopuszczając do zaszczytu ucalowania ręki. Po tym ceremoniahnym powitaniu z kobietami zabral głos gospodarz, uprzejmie zapewniając o swej ogromnej radości z powodu goszczenia monarchy 1 siebie. Następnie wznoszono okrzyki na cześć króla i rozlegały się wystrzały z dzialek wiwatowych, głośne i liczne, trwały zaś dopóty, dopóki Władysław nie wszedł do przeznaczonego dla niego pomieszczenia. Nieco wczéśnicj gospodarz

...ponownie mową wspaniała króla najjaśniejszego przyjął, a następnie odprowadził go na miejsce wypoczynku po trudach podróży, doglądając, aby nie brakowato gościom niczego.

Ta część wizyty ciaggnęla się do godziny trzeciej po południu.

Po pewnym czasie, jak grzeczność nakazywała, Radziejowski zapytał króla, kiedy podać posilek, choć wcześniej wszystko bylo przygotowanc i zaplanowane do najmniejszego szczegółu. Stół zastawiono wzdłuż całej jadalni, poproszono króla z braćmi o zajęcie miejsc. Tutaj ceremonial biesiadny znów był przestrzegany bardzo rygorystycznie ${ }^{11}$. Czołowe miejsce zajął król z królewiczami, a w niewielkiej od nich odległości (kilku lokci) usytuowali się senatorowie, dostojnicy i czlonkowie dworu, a także wojewodzina z wojewodziankami,

... aby miala towarzyszki nieopieszale w zachęcaniu tak znacznych gości.

Podano wodę do mycia rąk i ręczniki, królowi usłużył sann wojewoda. Zwyczaj ten przybył z zagranicy i nie przyjmował się łatwo przy sarmackich biesiadach, w XVI wieku mycie rąk przed posilkiem na wielu ucztach uważano za przesadę ${ }^{\prime 2}$.

Kiedy zaczęto spożywać trunki, wojewoda Radzicjowski wziął do ręki piękny kielich, stosownie wybrany na tę okoliczność, i zwrócil się do króla, wyrażając ogrommą radość, że może go przyjmować w swoim domu, i szczerze życząc pomyślności, po czym przepil lyk wina do

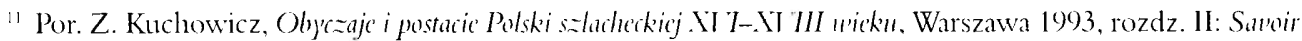

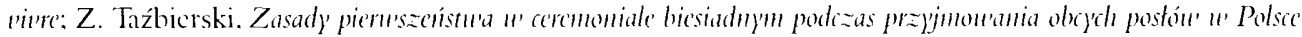
(XI 7-XI TII wick), ..Przegląd I Lumanistyczuy". R. 25: 1981, z. 3 (186).

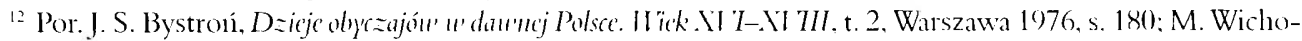

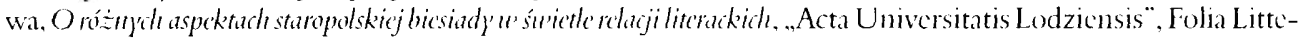
raria Polonica 5, 20(1) s. 3-12.
} 
króla i przekazał mu kielich. W tym momencie rozległ się wystrzał na wiwat. Następnie Władysław IV tym samym kielichem przywital brata Jana Kazimierza, i „kiedy król najjaśniejszy łyk wypil, dano trzy wystrzaly” (s. 33), a kiedy królewicz napił się, „dwa glośne rozległy się wystrzaly". To samo powtarzalo się z udziałem pozostałych królewiczów, a wszyscy spełniający ten kielich dolączali najlepsze życzenia szczęścia i bezpieczeństwa dla króla. Potem zaczęto dookoła przepijać z dostojnikami i członkami dworu, „do pierwszych powracając”, aż krąg się zamknął. Trochę później wojewoda rozkazal ,puchar słusznej wielkości, misternie wykonany" napełnić doskonałym winem węgierskim, podszedł do Władysława wraz z małżonką, która, skłoniwszy się do nóg królewskich, prosiła,

...jak zwyczaj uroczysty nakazuje i obowiązek matki rodziny wymaga, aby prawa nic naruszając przodków, kielich ów od niej w innię kielicha wszelkiej przyjaźni (crater philotesii), który dla zjednania nowej przyjaźni gości był wypity i w imię swojej dobroci i lagodności, by miał ochotę przyjąć (s. 33).

Władysław z początku się wymawiał, że przecież u Radziejowskich już bywal, ale wojewodzina perswadowała, że gości go po raz pierwszy jako króla, więc kielich przyjaźni przyjął,

...za przykładem króla najjaśnicjszego najczcigodniejsi także królewicze według sposobu czynienia tego poprowadzili i pozostali, którzy w imię nowych gości podjęli się tego i temu obowiązkowi poddali się.

W sumie ta ceremonialna radość, cieszenie się z po raz pierwszy przybyłych gości, trwała do trzech godzin, aż król z braćmi opuścił salę biesiadną i poszedł do komnaty, a gospodarz nadal kierowal się nakazami staropolskiej grzeczności i sumiennie dopelnial swych obowiązków. Wojewoda mianowicie odprowadzil Wladyslawa do przeznaczonej dla niego komnaty, tam jeszcze ze służbą dworską wypil kilka kielichów, życząc dobrej nocy dostojnemu gościowi i jego świcie. Wreszcie

...odszedl, aby tym rodzajem obowiązku, oddania i dobrej woli władcom najjaśniejszym przysłużyć się (s. 34).

Zatroszczył się o wygodę wszystkich pozostałych, wreszcie sam udał się na zasłużony spoczynek, utrudzony pelnieniem honorów gospodarza, który doskonale znat swe powinności w zadośćuczynieniu nakazom staropolskiej grzeczności. Tak minął pierwszy dzień wizyty.

Nazajutrz, we wtorek 23 listopada, odbyla się uroczystość chrztu synka Radziejowskich. Dzień zacząl się od mszy świętej, koncelebrowanej, upiększonej koncertem muzycznym. Następnie goście zwiedzili pałac, podziwiali ogród i zwierzyniec. Trwało to mniej więcej do jedenastej, wtedy bowien wszyscy udali się do kaplicy, ,aby syna najznakomitszego wojewody ze świętego źródła ochrzcić" Matką chrzestną była królewna Anna Katarzyna, nieobecna w Radziejowicach, więc w jej imieniu dziecko niosła podkanclerzyna Wielkiego Księstwa Litewskiego Sapiezyna. W początku uroczystości chłopczyka trzymała matka, następnie przejął go król jako ojciec chrzestny i zaniósł je do chrzcielnicy. Sakramentu udzielił biskup chełmiń- 
ski Jakub Zadzik; ochrzcił chłopca imieniem Whadysław. Matka w tym czasic, zgodnic ze zwyczajem, przebywala w imnym pomieszczeniu. Ochrzczonego synka odniosla jej czcigodna matrona, pani Rudzka. Po skoníczeniu uroczystości religijnej znów zaczęły się przyjemności towarzyskie. Grzeczność wymagała, aby gospodarz podziękował wylewnie ojcu chrzestnemu, totéz

...rzuciwszy się na kolana do króla najjaśniejszego podszedł i za tak szczodrą przychylność i okazaną laskę i wlożony trud (...) w najprostszych stowach dziękował (s. 35).

Znów rozlegly się strzały wiwatowe „bardzo glośno brzmiące”. Potem gospodarz przyprowadzil króla do pałacu, do zastawionego posilkami stołu.

Co gdy nastappiło, król najjaśniejszy przez wiclmożnego pana Rylskiego, swego podkomorzego, posłal do matki dziccka konterfekt z wyobrazeniem twarzy najjaśnicjszego Zygmunta III, króla Polski, ojca swojego.

Dar byl zresztą bardzo znakomity: wizerunek wykonano ze zlota czystej próby. Po kolei inni uczestnicy uroczystości składali podarunki dla oclırzczonego dziecka, na ręce rodziców „na znak radości z narodzonego syna”.

W tym samym czasie dania biesiadne pojawiły siç na stole, wojewoda, ponownie podchodząc do króla, powtórzył podziękowanie za laskę i dobrodziejstwa, po czym przystąpiono do spożywania posiłków, a spożywano je radośnie, bo uszy i dusze były pieszczone delikatną muzyką. Znów doszło do kielichów. Wtedy

...glowa rodziny według dawnego obyczaju z najpomyśninejszymi życzeniami dla najjaśniejszego króla jako pierwszy przepił, zapowiadając jeden głośny salıt armatni (s. 37).

W czasie, kiedy król z braćmi zachęcali do przepicia,

... pociski jakby bez żadnego porządku i odstępu, zgodnie z życzeniami i z wielkim lukiem detonowano.

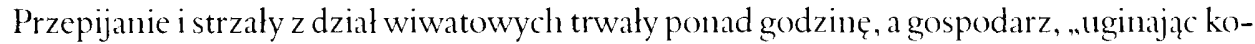
lana", senatorów i dostojników kielichem zachęcal do toastów, życząc szczęśliwego i ponysślnego zarządzania królestwem. Po czym nastąpiła przerwa, król z braćmi udał się na krótki odpoczynek, zjadł posiłek w towarzystwie gospodarza i brata Jana Kazimierza. Radziejowski tak to urządzil, że inna uczta była dla królewiczów, inna dla senatorów, inna dla urzędników, inna dla dworu, inna dla shuzby i inna w pokojach samego wojewody. Po raz kolejny król z bratem zasiedli do stołu w specjalne przygotowanej dla niego sali; gospodarz znów padł im pokornie do stóp i sławił niewiarygodną dobroć najjaśniejszych, zaś król prosil gospodarza i jego małżonkę o przedstawienie gości. Caly ten czas godnie i przyjemnie, a także spokojnie upły- 
nął ucztującym. Wojewoda popisywal się niezwykłą umiejętnością, tańcząc z kielichem pełnym wina podtrzymywanym na glowie, tak że nie uronił zadnej kropli podczas tanecznych podskoków, a „na różny sposób obracal się i kręcil”, co ze zdumieniem było obserwowane przez biesiadników. Tym samym kielichem przepijał do gości ustawionych wokoło, dopóki wszystkich nie obszedl. I tak zakończyl się kolejny dzień wizyty, w którym wojewoda Radziejowski - homo ludens - robil wszystko, by zadośćuczynić wymogom staropolskiej grzeczności i powinnościom gospodarza z niej wynikającym.

W trzeci dzień wizyty, we środę, dużo czasu przeznaczono na wypoczynek, potem odbyła się msza święta w kaplicy, przy muzyce, a po śniadaniu udano się na polowanie. Król Władysław IV był jednym z największych monarchów-myśliwych. Jemu właśnie Jan Ostroróg zadedykowal traktat $M_{y^{\prime}}$ sistu'o zogary'.. (1618) - pierwsze w Polsce, drugie w Europie dzieło poświęcone hodowli, leczeniu i ćwiczeniu psów gończych w umiejętnościach łowieckich. W przedmowie pisarz wyakcentowal dobitnie myśliwską pasję króla:

W tym tak wolnym a myśliwym narodzie urodziwszy się Wasza K[rólewska] M[ość| królewskim synem, urodzileś się zaraz i tak myśliwym, że ledwie kto jest, kto by się w tej zabawie barziej nad W. K. M. kochać się mógt ${ }^{13}$.

Zatem Radziejowski dobrze wiedzial, czym najlepiej udelektuje Wladysława w dniu przeznaczonym na odpoczynek. Król wyraził życzenie, aby zabawić się polowaniem. Podano śniadanie, a jednocześnie szczwacze i nagonka przygotowywali teren łowów, czyli zabezpieczyli go sidlami. Oczywiście bylo to polowanie umiejętnie reżyserowane. Nie wybierano się do dzikiej puszczy, lecz w pobliskim wąwozie wypuszczono schwytane wcześniej w sidła lisy i zające. Ta zabawa na świeżym powietrzu, z użycien psów myśliwskich, trwała około trzech godzin. Po zakończeniu, ,polowania” podano posiłek.

Tym razem „stoly wedłıg zwyczaju [jak należy sądzić — myśliwskiego - M. W.] poza domem poustawiano" (s. 41), i równie wystawnie, z takim samym zbytkiem jak poprzednio ucztowano, skladano królowi uszanowanie i kierowano do niego „tysiąc pozdrowień, tysiąc razy pomyślności i szczęścia” życzono. Po tym gospodarz odprowadzil króla do jego komnat, gdzie go odwiedzili biesiadnicy, życząc mu dobrej nocy. Następnie Radziejowski zabrał ich stamtąd, aby z kolei przekazać pozdrowienia na następny dzień dostojnikom, zaś pozostałych gości przyjąl w swojej kommacie. Wojewoda lęczycki, homo ludens,

...ile bylo można, używał życia wraz z gośćmi, i nie zakończono tych uciech, póki księżyc nie wstąpil pozlacanym grzbietem na wierzchołek nieba -

- mówi panegirysta. I tak zakończył się miły i wspaniały dzień okazalej gościny.

Gospodarz nie tylko z przyjemmością i niegasnącą ochotą pelnił obowiązki pana domu, ale także świetnie sic̨ bawił. W badanym panegiryku kreowany został na wzorzec osobowy, na

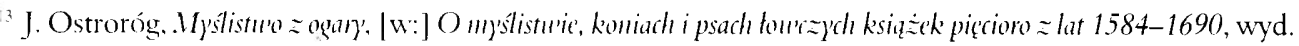
J. Rostatiníski. Krakíw 191+. s. 38. 
czlowieka posiadającego bezmiar talentów towarzyskich, pokazany jako człowiek zabawy, o Proteusowym obliczu. Umial w pełni wydobywać z życia to, co najlepsze, bawić się, całą duszą oddawać siç rozrywkom, czerpać zadowolenie z doraźnej przyjemnności, z wyzwolenia się od trosk dnia codziennego. Uczestnictwo w tańcach, żartach, ucztach, polowaniach przy doskonalej znajomości dobrych manier i obyczajów było jego żywiotem ${ }^{1+}$.

W ostatnim dniu pobytu obowiązywal rytual pożegnania. Grzeczność wymagala, aby dyskretnie zbierać się do podróży, co król nakazał swoim dworzanom. Gospodarz zaś, kierując się zasadami gościnności, najgorętszymi prośbami zabiegał u króla Wladyslawa o jeden dzień zwloki. „W każdym razie należalo tak prosić” — powiada autor. Jednak król, również kierując się zasadami grzeczności, prośbę odrzucil. Przystal tylko na to, że zje jeszcze poramny posilek w domu Radziejowskich. Zaś królewicz Aleksander na pożegnanie popisał się piçknym strzalem do jelenia znajdıjącego się w zwierzyńcu, w klatce z żelaznych prętów. Jelenia tego posłal Radziejowski królewnie Annie, matce chrzestnej synka, ,na znık wdzięczności i dowód podziękowania”. Znający się na grzeczności gospodarz zaopatrzył odjeżdżających w pożywienie i picie, które na odchodnym jest w zwyczaju przyjmować. Obdarowywano dla okazania wdzięczności za złożenie wizyty. Gość musiał otrzymać na pożegnanie upominek, czyli „gościniec”, a gospodarz żegnał wyjeżdżających „z wielkim bólem”. Również oni byli zobowiązani dzię̧kować za przyjęcie, i czynili to uprzcjmic, pozostając „równi w podziękowaniach" względem gospodarza. Wreszcie Radzicjowscy pozostali sami, a wojewoda zadbal, aby w krótkim czasie to zaszczytne dla niego wydarzenie uwiecznić w druku.

Zatroszczył się zwłaszcza o to, aby powstały opis wizyty stał się w znacznej części panegirykiem na jego cześć; poza tym jest to pismo o charakterze dokumentalnym i dużej wartości źródłowej; zamieszczone tam dane historycy (Ludwik Kubala, Adam Kersten) uznali za miarodajne. Przedstawione w druczku informacje są wiarygodne, gdyż autor przytacza treść listów i innych dokumentów z archiwum rodzinnego. Autorem jest jakiś bliski sługa swego chlebodawcy, „oddany powiernik” Radziejowskiego. Zestawił on wszystkie dalsze i blizsze koligacje rodzinne, na ich podstawie bez trudu można nakreślić drzewo genealogiczne wojewody. Takie opisy paranteli rodzinnych nie były wówczas czymś niezwykłym.

Sporządzanoje przy okazji ważnych wydarzeń rodzinnych, a więc ślubów, zgonów, narodzin potomka itd. Potwierdzenie pozycji było potrzebne przede wszystkim ludziom, których miejsce w hierarchii spolecznej nie bylo ustabilizowane. Sporządzali więc wykazy swych koligacji ci, którzy szybko pięli się ku górze albo ci, którzy równie szybko spadali w dól, zawsze w tym samym celu, dla wykazania więzów i podtrzymania splendoru rodı. Inspirując wyliczenie swoich paranteli, Stanislaw Radziejowski dawał jaskrawe świadectwo, iz ma

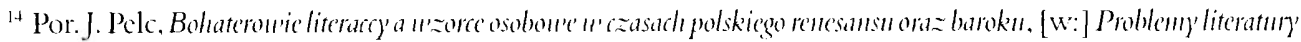
staropolskicj, seria 3, red. J. Pele. Wroclaw 1978.
} 
mentalność człowieka, który wdarł się już do magnackiej elity, ale bynajmniej nie uważa, że jego miejsce tam jest niepodważalne i utrwalone ${ }^{15}$.

Wojewoda, chcąc jak najpełnicj, najdobitniej wyrazić znakomitość swego rodu, kazał przedstawić nic tylko koligacje rodzinne, ale i swoje więzy przyjacielskie, a także zamiłowanie do wystawności, pragnienie jak najbardziej okazalego manifestowania swej wielkości. W opisywanych w Hospes... przejawach staropolskiej grzeczności dużo było teatralności, demonstrowania czołobitności względem króla i jego braci, choć - jak się wydaje — było to respektowanie pewnego obowiązującego rytuałı, manifestacja zewnętrzna. W istocie rzeczy ta gościna, przyponinająca chwilami widowisko parateatralne, starannie wyreżyserowane przez Radziejowskiego, służyła podniesieniu splendoru rodı. Poza tym gospodarz jako homo ludens, mający wybitne talenty towarzyskie, był w swoim żywiole, i z pewnością mial dużą satysfakcję z udanej gościny, bo przyniosta mu ona clıwalę i zarazem przyjemność. Sam zaś w inspirowanym przez siebie panegiryku głośno się przechwalał, dbając na każdym kroku, aby pokazać świetność jego rezydencji w opisie obejmującym szczegółowe wyobrażenie pałacu, poszczególnych sal (kaplica, jadalnia, apteka, biblioteka, kuchnia itp.), dziedzińca, parku, sadu, laźni, psiarni, zwierzyńca, a nawet kazal przedstawić .,wyjątkowy zbytek dań najwspanialszych i wyjątkowych” (s. 51), trunków, a przy tym - niepokalanie pięknych obyczajów.

Wreszcie, aby w pełni nakreślić niecodzienność wydarzenia, jakim była wizyta Władysława IV w Radziejowicach, autor pisma okolicznościowego zamieścil listę gości „bardzo wyjątkowych", jak wszystko wówczas prezentowane w gnieździe rodowym wojewody łęczyckiego. Twórca panegiryku dbał, aby jego pismo spetniało oczekiwania mecenasa nie tylko pod względem dokumentarnym, ale takze $w$ aspekcie artystycznym ${ }^{16}$. Stąd zadbal o staranne opracowanie literackicj ramy wydawniczej utworu.

Przed rozpoczęciem wlaściwego wywodu autor zamieścil dwa teksty, stanowiące „czoło” ramy wydawniczej, a więc wiersz laciński $N a$ oręż szlachecki, panegiryk na herb Radziejowskich i jego polski przekład, następnie fragment dzieła Cycerona O pou'innościach, zawierający pochwałę gościmności, bardzo stosownie wybrany i umieszczony, biorąc pod uwagę fakt, że stowa:

...jest bowiem bardzo zaszczytnym otwierać domy ludzi znakomitych dla znakomitych gości,

choć pochodzą od Cycerona, stanowią doskonałą alızję do wizyty króla Whadyslawa w Radziejowicach. Na końcu dzieła autor zamieścił wiersz Do Zoila, odpierając jakby potencjalne zarzuty stawiane pismu o wybitnie panegirycznym charakterze i powstałym zapewne przy współudziale Radzicjowskiego, przynajmniej w tym sensie, ze dostarczył on materiałów

\footnotetext{
15 A. Kersten. op. cit. s. 25.

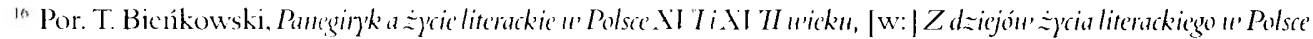
XT I i.XI II wicku. red. H. Dzicchcinska. Wroclaw 1980) (Studia Staropolskie t. 48), s. 183-196; idem, Rola pisa-

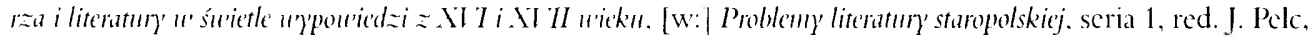
Wroclaw 1972, s. 223-267.
} 
o charakterze dokumentarnym, służących budowaniu jego wyidealizowanego wizerunku. Dzieło ma sławić wielkość rodu Radziejowskich, wiekopomne zasługi wojewody lęczyckiego, relacjonować przebieg wizyty króla, co też przynosilo chwalę gospodarzom. Prawem krytyka, szczególnie zlośliwego Zoila, podszytego zazdrością, jest dobre traktować jako złe, „przeszydzać, wykręcać, udawać” Autor byl zdolnym artystą, literacką ranę wydawniczą swego utworu zbudowal bardzo zgrabuie i przemyślnie.

Z przeprowadzonej prezentacji okolicznościowego pisma Hospes grati aninni... wynika, że stanowi ono ważny dokument źródłowy nie tylko dla historyka dziejów rodziny Radziejowskich, ale także dla historyka kultury i niezwykle smakowity kąsek dla historyka literatury badacza panegiryków. Ale ten aspekt pisma to material do analizy w innym artykule. 